\title{
Sacred History, Sacred Languages: The Question of Arabic in Early Modern Spain*
}

\author{
Mercedes García-Arenal and Fernando Rodríguez Mediano
}

Early Modern Europe was witness to an unprecedented interest in learning the Arabic language. This philological interest was connected to the evidence of Arabic similarity with Hebrew and the usefulness of Arabic grammars and dictionaries for studying the Holy Tongue. A field of knowledge was gradually created in which Arabic detached itself from its use as an instrument of proselytizing or diplomacy. This shift occurred through the translation and citation of Arabic sources, the purchase and cataloguing of Arabic manuscripts in the main libraries of Europe and an attempt to institutionalize the teaching of Arabic at universities. The exhaustive study of the Bible and its various textual traditions, the need to coordinate these with newly acquired knowledge of other languages, including Arabic, and the refinement of historiographic and philological tools which were the accompanying processes all contributed to dismantling the walls between sacred and profane history. This package of new knowledge can be labelled 'Orientalism'. As applied by scholars to this period, the term refers to a crucial moment in the creation of Oriental studies in Europe characterised by the foundational activities of figures like Erpenius, Raimondi or Bedwell. This refers to both their works and their search for new texts with which to learn Oriental languages. Such 'Oriental scholarship' or early 'Orientalism' proved itself capable of creating basic critical, historical and philological tools which were problematic for extant textual and religious authority. The religious dimension was ever-present in a world dominated by polemics with the Europe of the Reformation and by the process of confessionalization.

Ever since James Monroe published his well-known book on Arabic studies in Spain, scholars have argued that Spain played no part in the development of

* The research leading to these results has received funding from the European Research Council under the European Union's Seventh Framework Programme (FP7/2007-2013)/ ERC Grant Agreement number 323316, project CORPI, 'Conversion, Overlapping Religiosities, Polemics, Interaction. Early Modern Iberia and Beyond.' Martin Beagles translated this piece into English. 
Oriental studies in the late sixteenth and seventeenth centuries. ${ }^{1}$ It seems as if Spain was almost an Oriental country rather than a producer of Oriental scholarship. Other European nations characterised Spain as 'Oriental' in an effort to challenge its imperial dominion over other European countries. ${ }^{2}$ This interpretation remained the norm in Italy, France, and the Netherlands, and it caused much consternation among Early Modern Spaniards themselves, who acutely resented representation of their country as one embedded in Judaism and Islam. Italians spoke of the 'peccadiglio di Spagna' (not believing in the Trinity) to refer, with irony and disdain, to the mixed origin of Spaniards and their ambiguous religious identity. ${ }^{3}$ Erasmus of Rotterdam, in a famous letter to Thomas More in 1517, explained why he had turned down an invitation from Cardinal Cisneros to travel to Spain to work on the Polyglot Bible, writing that he did not like a country that was so deeply semitized. ${ }^{4}$ This representation of the country affected the position of Spain in Europe and its aspirations within the Catholic world. In relation to Italy, it was especially painful when Spaniards were living their so-called 'Italian hour.' ${ }^{5}$ The disdain provoked in Europe by the mixed origins of Spaniards created a game of mirrors in which Spain displayed a defensive attitude towards all belief deemed deviant within the heart of Hispanic Catholicism.

But it was during this same period that the study of Arabic and other Oriental languages, albeit fraught with difficulties, started to emerge, as we shall show in this contribution: in Spain, Arabic manuscripts were collected for noble or royal libraries, where they were catalogued and studied; chairs of Arabic were created at universities; Arabic sources were used for various scholarly endeavours, and Spanish scholars corresponded with their colleagues in other European countries and became aware of the role played in Rome by members of the Oriental Churches. ${ }^{6}$ However, such aspects will only be tan-

1 J.T. Monroe, Islam and the Arabs in Spanish Scholarship (Sixteenth Century to the Present), Leiden, 1970; and R. Jones's PhD thesis as discussed by G. Wiegers, 'Moriscos and Arabic studies in Europe', Al-Qanțara, 21, 2010, pp. 587-610.

2 J.N. Hillgarth, The Mirror of Spain 1500-1700. The formation of a Myth, Ann Arbor, 2003, p. 326 et seqq.

3 B. Croce, La Spagna nella vita italiana della Rinascenza, Bari, 1517, dedicated an entire chapter to the 'peccadiglio di Spagna'. S. Pastore, "Il Peccadiglio di Spagna": incredulità, scetticismo e política nell'Italia del primo Cinquecento', Rinascimento, 53, 2013, pp. 3-38.

4 Cited by M. Bataillon, Erasmoy España. Estudios sobre la historia espiritual del siglo XVI, Fondo de Cultura Económica, Madrid, 1991 [1966], p. 77.

5 'la hora italiana', J.C. Baroja, Vidas mágicas e Inquisición, I, Madrid, 1967, p. 217.

6 F. Rodríguez Mediano, 'Fragmentos de orientalismo español del siglo XVII', Hispania, LXVI, 222, 2006, pp. 243-76. 
gentially addressed in this paper. We are more interested in certain specificities which characterised the case of Spain. Most importantly, we will be interested, on the one hand, in problems related to the Arabic language itself within the Iberian Peninsula. Until the end of the sixteenth century Arabic was spoken and written in some parts of Spain (mainly Granada, Valencia and some parts of Aragon) by its population of Muslim origin, generally known as Moriscos, who were often crypto-Muslims. The elite of these converted Muslims was also interested in producing and collecting Arabic books and was conscious of the difference between their own spoken dialect and Classical Arabic. This created a context in which Spanish scholars would therefore move between erudite knowledge and practical experience.

On the other hand, the converted Muslims were the remains, and a constant reminder, of the medieval history of Iberia. During the Middle Ages, part of the peninsula had been under Islamic political control, a polity known as al-Andalus, and had later experienced a long, slow and uneven process of Christian conquest that early modern Spaniards perceived in terms of the loss and recovery of Spain', or the so-called 'Reconquista'. This would require early modern Spanish historians to make difficult decisions in terms of interpreting continuity or rupture within certain periods of the Iberian past.

The end of the Reconquista was followed at the beginning of the early modern period by a powerful movement towards conversion and expulsion with Messianic and providentialist overtones which affected Jews and Muslims. This movement stressed the need for integration and homogenization, but also argued for expulsion and purification. It was legitimized by a providentialist interpretation of the past of Spain as a 'nation' forged during the struggle against Islam. Arabic was an undeniable part of it all.

The Arabic language in Spain was identified with Morisco Islam, but was also put to practical uses in a complicated contact zone, the frontier with Muslim Granada and with the Maghreb. It was a forbidden language and its prohibition was enforced on the population of Muslim origin, and partially also on all subjects of the Crown of Spain, but the language was considered to be of practical use for dealings with North Africa and of scholarly importance for scientific matters. Especially, it was useful for reading Arabic sources in order to write the history of Spain and know the history of the Spanish language. The presence of an Arabic and Muslim tradition distinguished the Spanish experience from other European regions in such a way as to uniquely affect that nation's undertaking of the study of the Arabic language. Within the broad scope of the scholarly knowledge and use of Arabic in early modern Spain, this brief essay will be focused on the issue of writing Spain's sacred history. Specifically, it will examine the conflict between dialectal Arabic and 
classical Arabic, which was simultaneously a conflict between local Morisco culture and the culture of Eastern Arab Christianity prevailing in Rome and other places. The main purpose of this study is to explore why certain individuals varied in their usage between a dialectal Arabic used by the Moriscos and learnt by those who moved among them and a Christian classical Arabic linked to Hebrew which could be used to write sacred history. This became a case of tradition, history, scholarship and local knowledge versus the classical model, and such are the tensions to be addressed here. Additionally, this essay will incorporate discussion of how Moriscos and erudite Orientalism were intertwined, of the ambivalence towards the learning and use of Arabic that it produced and of the attempts made to resolve this ambivalence through efforts to 'de-Islamize' the Arabic language.

In order to contextualize the complex cultural environment which the Arabic language produced in Early Modern Spain, and in order to understand these efforts to de-Islamize it, it is necessary to attend to a series of events which agitated the conflict. Ambivalence towards Arabic did not only come about because of Spain's medieval past, but also because of its early modern present.

\section{Prohibiting, Burning and Keeping Arabic Books}

This ambivalence is best exemplified by the following very famous event: in 1500, the Cardinal and Inquisitor Francisco Giménez de Cisneros, in the midst of a campaign to enforce the conversion to Catholicism of the Muslim population of Granada, ordered all Arabic books in the city to be confiscated. He organized a public burning of Qur'āns and books pertaining to religion and ordered all scientific, medical and astronomical books in Arabic to be sent to the library of the university that he had created a few years earlier in Alcalá de Henares, where he initiated the project of compiling the first polyglot Bible, the Biblia Políglota Complutense. The same university of Alcalá was the first to have a chair of Arabic, initially held by Diego de Urrea, an Arabic interpreter of Italian origin who had lived for years as a captive in the Maghrib and had worked in diplomatic missions. Urrea and others like him, including several Moriscos who will be mentioned below, also worked on the cataloguing of Arabic Manuscripts in the Royal Library at El Escorial and as translators in the affair of the Lead Books of the Sacromonte, also to be covered below. Ambivalence, prohibition, burning, conservation, and the scholarly study of Arabic books thus all come together in the order made by Cisneros.

Forced to convert to Catholicism at the beginning of the sixteenth century, the Moriscos kept many of their cultural traditions and practices and were 
perceived as inassimilable despite their formal conversion. After the conquest in 1492 of Granada, the capital city of the last Muslim Kingdom in Iberia, and the first decrees of conversion (i.e., between 1499-1502), the first campaigns of evangelization of the Muslim population witnessed the use of Arabic by the missionary priests. Archbishop Talavera took a printing press to Granada and used it to produce catechisms in Arabic, as well as glossaries and small grammars (most famously the Arte para ligeramente saber la lengua arábiga of Pedro de Alcalá, published in 1504), and texts written in Arabic but with the Latin alphabet for use by priests who knew little or nothing of the language. ${ }^{7}$ These attempts to learn and teach Arabic for missionary activities were shortlived: by the middle of the sixteenth century Arabic, closely identified with Islam, had come to be considered an obstacle for the conversion of Muslims. Church and civil authorities both took the view that in order to uproot Islam as a religion, the language had to be erased. ${ }^{8}$ It is worth noting that the Arte of Pedro de Alcalá reflected not classical Arabic, but the local, Granadan vernacular: from the beginning of the sixteenth century the diglossia of two different levels of Arabic had become evident, with its effect on the teaching of the language and also on the need for Iberian Arabophones to learn the classical version of the language.

Throughout the sixteenth century, and more intensively from the mid-century, the Spanish crown, local authorities, and the Spanish Inquisition enacted policies to confiscate Arabic books and in general to erase the Arabic language, in line with the policy laid down by Cisneros in the event mentioned above. In 1511 Queen Juana of Castile issued a general pardon to all Moriscos possessing Arabic books if they brought them before the authorities to be examined for the themes they covered: books of philosophy, historical chronicles and texts on medicine would be given back to their owners, but the rest would be burned. ${ }^{9}$ In 1564, the Cortes of Valencia forbade the Valencian Moriscos to speak or write in Arabic; in 1567, Philip II banned the use of spoken and written Arabic in the territories of the Crown of Castile, and in response, the Inquisition began confiscating, storing or burning Arabic manuscripts. The decree of 1567 produced consternation and anger among Granadan Moriscos (who were still mainly Arabophone) and was the main reason for the ensuing Morisco revolt known as the War of the Alpujarras (1568-70). This war, which lasted two years

7 M. García-Arenal, 'Granada as a New Jerusalem: The Conversion of a City' in Space and Conversion in Global Perspective, eds G. Marcocci, W. de Boer et al, Leiden, 2014, pp. 15-43.

8 M. García-Arenal, 'Is Arabic an Islamic language? The religious identity of the Arabic Language and the affair of the Lead Books of Granada', Arabica, 56, 2009, pp. 495-528.

9 'Copia del registro indultando a los nuevamente convertidos que tuvieren libros en arábigo', 20 June 1511, Colección de Documentos Inéditos para la Historia de España, 39, pp. 447-50. 
and was an especially ferocious conflict, led to a new Christian conquest of the Kingdom of Granada and ended with the enforced banishment of Granadan Moriscos to Castile. It changed for ever the relations between Moriscos and Christian society. In 1593, the ecclesiastical authorities in Saragossa announced that Moriscos who owned books in Arabic could hand them in and be pardoned, in an edict very similar to the one mentioned above of Queen Juana. All the above-mentioned measures and many more that insisted on the same prohibitions led Arabic to be identified with Islam and with the secret practice of Islam. The restrictions on Arabic were supposed to uproot the Moriscos' apparently persistent belief in Islam and to complete their conversion to Christianity. Part of the Morisco community continued trying to learn Arabic and kept Arabic books until their expulsion from Spain in 16o9: several important hoards of books were found buried or hidden in their houses after they were forced to leave. In sixteenth-century Spain, therefore, Arabic books were written, copied and brought from North Africa by Moriscos. There were also books translated from Arabic by the same Moriscos and written in what is called aljamía, the Spanish vernacular in Arabic script, a sort of Islamic version of Spanish. Both Arabic and Aljamiado texts were sometimes destroyed and sometimes kept in secret by the Moriscos but also, after being confiscated by the Inquisition, held in several collections that reached the royal library and the libraries of noble houses, and contributed to the construction of a scholarly discipline. Scholars such as Bernardo de Aldrete looked out for some of those books confiscated from the Moriscos in order to obtain them for their own use. ${ }^{10}$

The bans on Arabic books were directed mainly at the population of Muslim origin. With other aims and for other causes, further prohibitions were imposed on all Spanish subjects in the form of the 'Indices' or indexes of forbidden books that were basically a response to the Protestant Reformation. The famous Valdés Index of 1559 declared that books 'of the Mohammedan sect written in Arabic or in Romance or in any vernacular language' were forbidden. ${ }^{11}$ But at the same time as Inquisitors and the Crown sought to purge the public space of Arabic, scholars - some of whom worked with the Inquisition - and the King were collecting Arabic manuscripts for the royal library at El Escorial. ${ }^{12}$ The library, today one of the most important repositories of Arabic

10 M. García-Arenal, F. Rodríguez Mediano, 'Los libros de los moriscos y los eruditos orientales', Al-Qanțara, 31.2, 2010, pp. 611-46.

11 A.S. Corella, La censura en España. Índices y catálogos de libros prohibidos, Madrid, 1947, p. 232.

12

D. Hershenzon, 'Traveling Libraries: the Arabic manuscripts of Muley Zidan and the Escorial Library', Journal of Early Modern History, 18.6, 2014, pp. 535-58. 
books in Europe, was founded by Philip II between 1563 and 1584. Scholars and humanists of renown, the likes of Juan Páez de Castro, Juan Bautista Cardona and Ambrosio de Morales, participated in its creation and endowment. When Páez de Castro died in 1570, his library, which contained several Arabic manuscripts, was sent to El Escorial, as was the library of Diego Hurtado de Mendoza. ${ }^{13}$ The King had ordered that his library at El Escorial should hold and preserve forbidden books. The tension between the prohibition of Arabic manuscripts and the purchase, collection and study of them is best seen in the person of the renowned Hebraist and humanist, as well as head librarian at El Escorial, Benito Arias Montano, who helped to draw up various indexes of prohibited books for the Inquisition. At the same time Arias Montano was interested in buying Arabic books of all kinds, including Qur'āns, for the Royal Library. He acknowledged the existence of forbidden books at El Escorial, but argued for the importance of keeping them there. ${ }^{14}$ Morisco men of letters also worked at the library. The Granadan Morisco Alonso del Castillo, physician and translator of Arabic ('intérprete real') and an interpreter for the Inquisition, catalogued books and documents confiscated by the Holy Office. He also worked for many months at the library at El Escorial and drew up the catalogue of Arabic books there which Johann Heinrich Hottinger later used in compiling his own Latin catalogue of $1658 . .^{15}$ Another Morisco physician, Miguel de Luna, also worked in the Royal Library and produced a famous book on the Islamic conquest of Iberia which he presented as the translation of an Arabic chronicle he had consulted at El Escorial. This was his Historia verdadera del Rey Don Rodrigo, first published in Granada in 1592, an instant bestseller which was immediately translated into several European languages. The Historia verdadera was a wellcrafted fake, which cleverly used a supposed Arab chronicle as a means to give authority to its invention. This option taken by Luna indicates a re-evaluation not only of Arab texts as faithful sources for writing the history of Spain, but also the role of Arab culture within Spanish culture. Both Castillo and Luna were part of a small cultivated Morisco minority who read and wrote Classical Arabic, and both were connected with the famous forgery known as the Lead Books of Granada.

13 N. Morata, 'Un catálogo de los fondos árabes primitivos de El Escorial', Al-Andalus, 2, 1934, pp. 87-94.

14 'Memorial de los libros vedados que se hallan en la librería de S. Lorenzo el Real' in B. Rekers, Benito Arias Montano (1527-1598), Leiden, 1972, p.162; and D. Hershenzon, 'Traveling libraries' p. 546 et seqq. 


\section{The Lead Books of Granada}

The Moriscos were a complex Islamic group, open to the transmission and translation of religious ideas, images and emotions from the Christian milieu within which they lived. Subjected to the pressure of intense polemic, they could not help but define themselves through their confrontation and interaction with the world around them. Persecuted by the Inquisition and under pressure from the civil authorities they deployed different and highly interesting strategies to try to salvage aspects of their culture, literature and language. The Memorial that the Morisco nobleman Francisco Nuñez Muley wrote to the Audiencia (High Tribunal) of Granada in 1567 arguing against the edict prohibiting the use of the Arabic language and written documents, including family names and lineages as well as other customs such as baths, dress, haircuts and music, is one of the best known and moving examples of the efforts of a Morisco elite to defend parts of its own language, tradition and memory. ${ }^{16}$

But by far the most interesting illustration of both the complexity of Morisco elites and their efforts to preserve a part of their culture is the forgery known as the Lead Books, produced in Granada in the late sixteenth century and miraculously 'discovered' in the hills near the city, since known as the Sacromonte. Like the Memorial of Núñez Muley, these books can be considered a response to the edict of 1567 and to the ensuing War of the Alpujarras and its consequences. The Lead Books consisted of a series of texts written in Arabic on circular sheets of lead, in a supposedly ancient slanting Arabic script without diacritics or vowels, similar to the kind of writing used in talismans and magical writings. These works claimed to be a text from Christian antiquity, including a gospel dictated in Arabic by the Virgin Mary to a group of Arab disciples who had travelled with Saint James to Spain, where they founded the city of Granada and were martyred. This is a case of an allegedly Christian text constructed from Islamic sources: no references are made in it to any of the aspects of Christianity deemed unacceptable to Islam, such as the divine nature of Christ, the Holy Trinity, worship of images or oral confession. The stories from the life of Jesus which it contains are taken from the life of Muhammad, and its vocabulary and spirituality are clearly Islamic.

The forgery was carried out by Moriscos who had targeted two groups of potential readers: firstly, the Christian Church and civil authorities, to whom

16 Published fully as an Appendix to B. Vincent's 'Introducción' to the new edition of A. Gallego y Burín and A. Gamir Sandoval, Los moriscos del Reino de Granada según el Sínodo de Guadix (1554), Granada, 1996, pp. XxxIX-LII. Translated into English by V. Barletta as A Memorandum for the President of the Royal Audiencia and Chancery Court of the City and Kingdom of Granada, by Francisco Nuñez Muley, Chicago, 2007. 
they wished to prove that Arabic was a Christian language and that there was therefore no reason to ban its use. They also sought to persuade this group of readers that the first Christians in Granada had been Arabs and that the Moriscos were therefore fully-fledged Granadans and not aliens who could be expelled. However, the text could also be read from a Morisco point of view as a text of religious polemic directed against Christianity, as well as a way of upholding an eschatological dissimulation (that is to say, one in force until the End of All Time, an event understood to be imminent) which spoke of a Christianity that had been cleansed and made admissible to secret followers of Islam. The text of the Lead Books showed a profound knowledge of the boxes that had to be ticked in order to guarantee the success which it certainly enjoyed among the Christian authorities of Granada and the Spanish population in general. It provided 'proof' of Saint James's journey to Spain, it spoke of the Immaculate Conception of Mary, and it offered up relics ensuring the sacred origin of Granada and the existence of the city before the arrival of the Muslim invaders. The Lead Books were tremendously successful and continued to be deemed genuine even after they were anathematized by the Vatican in 1682, a century after their first 'discovery', when Pope Innocent XI declared them to be false.

What most interests us about this whole affair is the boost it gave to an erudite, philological study of Arabic. From the moment the Lead Books were found, the Church in Granada, through its Archbishop Pedro de Castro, and the Spanish Crown, defended the Books' authenticity with passion; thus the affair of the Lead Books gave rise to a tremendous debate and to a long and varied series of translations and linguistic studies. As our book The Orient in Spain shows, the matter went far beyond the confines of Granada's local history and of the Morisco problem in the region. ${ }^{17}$ It was to engage the Spanish Church and Crown, the Vatican, the bishops in their struggles with Rome, and the scholars and humanists of half of Europe.

The affair of the Sacromonte Lead Books transformed both the knowledge and the use of Arabic in Spain, at the same time as it provoked an abrupt turn in the historiographical study of the Peninsula's Islamic and pre-Islamic past. Through the study of those who translated and debated the authenticity of this supposed ancient Arabic Christian text we come to know a core group of scholars who counted the knowledge of Arabic and Oriental languages among their principal interests. This group's activities reveal the development of a learned or scholarly use of the Arabic language in Spain. Most interestingly we can see, through the study of the Lead Books, how the interests of these scholars came

17 García-Arenal and Rodríguez Mediano, The Orient in Spain. 
to coincide with the interests of the Moriscos who had forged them. Both groups needed to create a clear sense of separation between the Arabic language and the religion of Islam, a separation that was one of the main aims of the Lead Books. This was a reaction to the prohibition of Arabic in 1567. It also sought to present a very old 'native' population of Arab Christians, the first Christian martyrs in Spain. In this version of events, Arabophones could be Christians, and so old that they could not be expelled.

The Lead Books of Sacromonte show up how the issue of the use of Arabic had become part of the general problem of writing the sacred history of Spain. That a language so strongly identified with Islam and the very recent Muslim past of the Iberian Peninsula should have become part of the history of the evangelization of Spain can only be understood in the light of the complex process of de-Islamization of the Arabic language and the important and audacious programme surrounding that process. This also applies to the idea that Arabic was not introduced into Spain by the Muslims, but was spoken before the conquest of 711 and was a Christian language, as is proved by the existence of the Eastern Arab Christians and their texts.

We have sound evidence that the Morisco Miguel de Luna, the author of the fake Historia verdadera del Rey Don Rodrigo, was one of the authors of the forged books as well as an apologist for their authenticity. Alonso del Castillo was another Morisco interpreter who worked on the translation of the Lead Books. Both of these men were physicians educated at the University of Granada and had knowledge of Latin. Both worked at El Escorial, and Castillo even made an inventory of the Arabic manuscripts held there, as was mentioned above. He also transcribed and translated the Arabic inscriptions of the Alhambra, as well as letters sent by the Moroccan sultan Muley Ahmad alMansur. To close the circle linking the Moriscos to the erudition of Oriental philologists it is worth mentioning that this same Alonso del Castillo claimed in his diary to have learnt classical Arabic from the Flemish humanist Nicolas Clenaerts.

The Sacromonte forgeries, with their huge corollary of passions, polemics, translations and circulation of books and ideas, help us to think of several crucial processes in the issue of early modern Spain's relationship with Arabic: firstly, the difficult integration, in the history of the Spanish language, of another tongue which, like Arabic, was closely identified with Islam and with the Moriscos suspected of being crypto-Muslims; secondly, the integration of the Arabic past in the writing of the history of Spain and in the construction of a historical narrative and a homogenous cultural model. As we will attempt to show in the pages that follow, these conflicts come together around several problematic issues: the de-Islamization of the Arabic language, the transition 
from local Morisco culture to scholarly culture, and from dialectal to classical Arabic. The rest of the article will show that Spain did participate in the emergence of modern European Orientalist culture and will characterise this participation.

\section{Writing History}

The writing of history was a problematic and productive endeavour in Early Modern Spain. By the end of the sixteenth century we find a broad and wellfounded corpus of historical writing that brought together all that was known about the medieval wars that ended with the final defeat of the Muslims by the Catholic Kings. The theme of Islam and the Arabic language in Spain is everpresent in these early modern historical narratives centred on the problem of integrating the history of al-Andalus into the history of Spain. National history implied a national territory, so was al-Andalus Spain or was it not? Could one trace a continuous thread, in spite of the supposed break that al-Andalus represented in Spain's medieval history? Could the linguistic, communal, or archaeological remains of Arab culture be incorporated into a 'Hispanic' identity? All of these questions underlie early modern Spanish historiography, and emerge in dramatically problematic form at certain moments when the tension between rejection and acceptance of the Muslim past rises to the surface. It is not surprising to find this contradiction expressed in texts about the ancient glories and monuments of Spanish cities, especially cities that had an evident Islamic history. In such works it became necessary to present the conversion of Andalusian cities into Christian ones. The cities of early modern Spain wanted their history written not as a mere process of transformation or creation but as one of restoration. Above all, it affected the scholarly approach to the Arabic language. It was not only the territory and national history that were 'infiltrated' by the Islamic past. Spanish, the language itself, was known to be influenced by Arabic and therefore Arabic was needed to improve knowledge of the history of Spanish. It was not only national history and territory: different scholars identify a significant form of linguistic nationalism in early modern Spain. The idea that there should be one unique national language and that this language was an important unifying characteristic for national identity and was endowed with historical legitimacy was very clearly expressed. ${ }^{18}$ in Early Modern Spain', Journal of Linguistic Anthropology, 14, 2004, pp. 57-80. 
From the moment in the late fifteenth century when Spanish was studied and historicized, and grammars and dictionaries came to be written, it became clear for a considerable number of scholars that Spanish was a language infused with Arabic forms and vocabulary, i.e., that Arabic was part of Spanish and that this made Spanish different from other Romance languages. There is a rich corpus on the place and role of Arabic in Spanish. Some of these accounts are extremely self-conscious about evincing the role of Arabic in the Spanish culture of the time. Many of the debates about Spanish culture and its relation to the Moors and Islam after the fall of Granada took place around the issue of language. It was not a discussion which concerned only erudite or learned people. We find it in literature, in the Romancero, or in Don Quijote. ${ }^{19}$ Other vernaculars in the peninsula, competing for prestige, accused Castilian of being the most infused and influenced by Arabic of all the peninsular languages. We will quote only one meaningful example, that of Rafael Martí de Viciana (1502-1574) who, in his Libro de la alabanças de las lenguas hebrea, griega, latina, castellana, y valenciana (1574), defended the idea that the Valencian vernacular was superior to Castilian because of the intense linguistic borrowing from Arabic in Castilian and the implications of this borrowing. For example, Castilian territory was contaminated because of its toponymy, with all the names of its rivers starting with the Arabic word 'Guad'. The implications included de Viciana's notion that Castilian incorporation of Arabic words into its lexicon was not inseparable from the religion of Islam and therefore from linguistic and religious corruption.

Toponymy and etymology were necessary, and amply used in works that aimed to discover the origins of peoples and the histories of their regions, and struck at the core of some of the most controversial aspects of Spanish history and self-understanding. In Spain, as in the rest of Europe, etymologies became in the early modern period an important, albeit always contested, pillar of historical writing. ${ }^{20}$ In Spain one matter which cropped up constantly in

19 Toward the end of Part II of Don Quijote the protagonist speaks about musical instruments, among them 'albogues': “What are albogues?" asked Sancho "[...] I've never heard of them or seen them in my life." "Albogues" responded Don Quixote "are something like brass candlesticks, and when you hit one with the other along the empty or hollow side, it makes a sound that is not unpleasant [...].this word albogues is Moorish as are all those in our Castilian tongue that begin with al, for example: almohada, almorzar, alhombra, alguazil, alhucema, almacén, alcancía and other similar words, [...] those which end with the letter í, and are borceguí, zaquizamí, maravedí, alhelí". Quoted in B. Fuchs, Exotic Nation. Maurophilia and the Construction of Early Modern Spain, Philadelphia, 2009, p. 25. See A. Vine, 'Etymologies, Names and the Search for Origins: Deriving the Past in Early Modern England', The Seventeenth Century, 21.1, 2006, pp. 1-21. 
historiographical discourse was the position of Jewish and Muslim people and cultures in a Spanish society dominated by the legislation regarding limpieza de sangre. In response to concerns over the status of Castile within the peninsula and in relation to other peninsular vernaculars, the loyalty of the recently converted Muslims or the position of Spain within Europe and Christendom, Spanish scholars increasingly placed language at the centre of their historical investigations.

In relation to this 'nationalistic' approach to language, there was also an ongoing controversy that concerned the historical origins of the Spanish language (or Castilian/Romance, the terms being used interchangeably in this period). From the paradigm of the Tower of Babel in the Book of Genesis to theories on the cyclical rise and decline of languages, different strategies appear in these emergent linguistic studies. Juan de Valdés's (1509-1541) well-known Diálogo de la Lengua (1535) argued that Castilian emerged from decadent Latin, in which he was following Antonio de Nebrija's theory in his Gramática de la Lengua Castellana (1492) on the origins of this Romance language. But this explanation did not go unchallenged. No mere matter of a succession and mutation of forms, the attribution of historicity to the Spanish language, with its implications of inconstancy, corruption and human invention, was seen by those opposing the idea that Spanish derived from Latin as an insult to the Spanish nation. ${ }^{21}$ One side argued that Castilian was derived from Latin, the other claimed that Castilian had been created by God at Babel and brought to Iberia by Noah's offspring after the Flood, long before the Romans arrived. At the basis of this dispute were two completely distinct approaches to history. ${ }^{22}$

\section{Continuity and Change}

The extent to which all of these problems concerning the origin of Spanish, the sacred history of Spain and the presence in it of Arabic culture, come together in the Sacromonte affair, is well illustrated by the correspondence between Bernardo de Aldrete and Archbishop Pedro de Castro, which has been studied by Kathryn Woolard. ${ }^{23}$ Archbishop Castro was, as we have said above, the main supporter of the Sacromonte forgeries, according to which the Arabic and

$21 \quad$ Woolard, 'Is the Past a Foreign Country?', p. 58.

22 K.A. Woolard, "'Bernardo de Aldrete, Humanist and Laminario', Al-Qanțara, 24.2, 2003, pp. 449-76; 'Bernardo de Aldrete and the Morisco Problem: A Study in Early Modern Spanish Language Ideology', Society for Comparative Study of Society and History; and J.C. Zamora, 'Ideología, filología, y lingüística en la gramática española del renacimiento', Hispania, 70.4, 1987, pp. 718-23.

23 See: Woolard, 'Bernardo de Aldrete'. 
Spanish languages were both spoken in the Iberian Peninsula in the first century AD. Bernardo de Aldrete (1560-1641) was a leading scholar, a canon of the Cathedral of Córdoba and author of one of the most important books on the origins of the Spanish language, Del origen y principio de la lengua castellana o Romance que oy se habla en España. In it, Aldrete authoritatively defended the theory that Castilian was corrupt Latin and not a primordial language in itself, and this was the reason why the work had burst strongly into contemporary debates on the origin of Spanish. When Pedro de Castro read Aldrete's book, he immediately realized that it demonstrated that Arabic had been introduced into Spain by the Muslims and that the Spanish vernacular had begun life during the period of the Visigoths as a corrupt form of Latin. Such ideas directly contradicted his own, as well as what seemed to be shown by the Sacromonte Lead Books, namely, that Arabic was spoken by ancient Christian Arab martyrs and arrived in Spain in the first century AD.

The correspondence between Castro and Aldrete is highly interesting for several reasons: their linguistic discussion of the languages of Spain, and of the chronology of the use of Arabic or Spanish, evokes the broader conflict between two opposing models of the history of Spain. It also shows how a scholar like Aldrete could be placed under pressure by a man such as the Archbishop, who did not hesitate to bring his authority, and that of the Church's holy saints, to bear. At the end of the correspondence between the two men, Aldrete was put under considerable pressure by Castro and persuaded to acknowledge the providential nature of the Lead Books, written in Arabic, thereby admitting the pre-eminence of the notion of writing Spain into sacred history over that of carrying out a purely linguistic interpretation of the origins of the Spanish language.

In one of his most important works, Varias antigüedades de España y África, Aldrete reproduced, in an anonymous manner, a letter from the Archbishop defending the antiquity of the use of Spanish and Arabic in the peninsula: 'You argue that the Spaniards took the Arabic language from the Muslim Moors, and say that it occurred in only a few years; and in other places you say that in Spain the Phoenician and Carthaginian Punic tongues were spoken, and that these nations or languages entered Spain long before the Romans. I have heard doubts expressed, since these nations entered Spain so much earlier, whether they brought the Arabic language, or whether it was Punic or Phoenician, or another that came in together with them, because it seems to them [the objectors] that the Spaniards had a very long time to take the language of the Carthaginians or Arabs [...]. And it seems to them that this long period was a likelier time for this language to have been introduced into Spain than the moment when the Muslim Moors entered, and for this reason they say that 
there are names of rivers, towns and others in Arabic dating from a period long before the entry of the Muslims in Spain. ${ }^{24}$

As we have seen, all the authors of treatises on the history of the Spanish language had encountered the problem of the existence of a large number of words and place names of Arabic origin, and this problem was discussed within the framework of the broader issue of continuity and rupture in history. In opposition to Archbishop Castro, Aldrete himself devoted a chapter of his Varias antigüedades to the issue of 'the great change brought about in Africa by the coming of the Mohammedans', where he explained that 'the change caused in all things by the Mohammedan Saracens when they entered every province was so great that it brought about grave damage in Spain. It was the same or even greater in Africa, where they changed and altered the names of towns, cities, peoples, mountains and rivers, and the vestiges and signs of the originals have scarcely survived. This was noted by Mármol, the reputed author of a Descripción de General de África (1573) who, as quoted by Aldrete said that the Arabs, in order to remove old memories, changed their names and although they left some of them, they changed others at will. 'And the same was done by the Africans after the decline of the Mohammedan tyranny, and in the wars many provinces were destroyed and others re-built. From this great change and alteration it follows that one can learn about antiquity only with great difficulty, that time itself would be enough to erase it even without these accidents, and it is even worse when they have been so violent; and thus it is that we advance more by guesswork and conjecture than along a clear and open path, for even the books which dealt with these events were removed by the Mohammedans. ${ }^{25}$ The idea that the arrival of the Muslims had represented a historical rupture, which was reflected in a massive change in toponymy, was repeated with a certain frequency. For example, the great Jesuit historian Father Juan de Mariana had written of the Muslims: 'There is no doubt that along with the change there was in other things there were changes of name in many towns, mountains, rivers and springs, resulting in great confusion in the memory and ancient names, as the barbarous leaders seem to have wished to perpetuate their memory and to their greater honour found new towns or change the names of others which had stood since ancient times.'26

\footnotetext{
24 B. de Aldrete, Varias antigüedades de España, África y otras provincias, Antwerp, 1614, p. 56 .

25 Ibid., p. $45^{2}$.

26 J. de Mariana, Historia de España, in Obras del padre Juan de Mariana, Madrid, 1950, I, p. 188 .
} 
The discussion between Castro and Aldrete was, then, part of a broader debate about continuity and rupture in history; ${ }^{27}$ as was argued in some theoretical treatises on history, this topic was central to constructions of the very concept of 'tradition': '[Tradition] has the same force in the [geographical dimension of History], explaining in which place that which is being told occurred and how the town was founded and who its first inhabitants were and what illustrious citizens it had in it, all is born from the accounts passed on by the elderly to the young, whose memory today serves as history by tradition. How many towns are there in Spain, where even today there is still discussion concerning whether they are or are not what is said in Roman histories?'28 This quotation from Cabrera de Córdoba places the etymological and toponymic issue on a double plane: that of local knowledge, which was transmitted orally from parents to children and which laid the groundwork of tradition; and that of toponymy, seen as a key to understanding historical forms of continuity.

\section{The Origins of Spanish and the Orient}

But what kind of continuity and rupture underlay the discussions between Castro and Aldrete? The idea, defended by Aldrete, that Spanish derived from Latin, and was no more than a corrupt form of Latin, was discussed by several scholars from the moment of his book's first appearance. The example of Archbishop Castro is an indication of how Aldrete's book was received in Granada, i.e., in the Granada of the Lead Books of the Sacromonte, and of how the response to Aldrete's thesis of the historicity of languages and chronological rupture was almost immediate. Thus it was that Francisco de Ulloa Solís wrote a short treatise listing the ways in which Spanish grammar differed from Latin. Ulloa also underlined the points which made Spanish a singular language unlike any other, or, more interestingly, the ways in which it resembled Hebrew, Aramaic, Arabic or Greek. He found many such points of similarity: ' $h$ ' was a consonant, as in Hebrew, Aramaic and Arabic; the superlative was formed with 'muy' [very], as in Hebrew; on occasions, as in Hebrew, the gender of masculine nouns could become feminine for reasons of euphony. Ulloa also made reference to several features of verb tenses in which Spanish 'imitates' the holy tongue. ${ }^{29}$

27 Woolard, 'Is the Past a Foreign Country?'.

28 C. de Córdoba, Luis, De historia, para entenderla y escribirla, ed. S. Montero Díaz, Madrid, 1948 , p. 65.

29 'Algunas diferencias entre la gramática castellana y la latina de Francisco de Ulloa Solís, enviadas por el padre Cartujo a Aldrete', in J. Rubio Lapaz, Pablo de Céspedes y su círculo. 
The case of Granada shows the full extent of the problem of the etymology of place names, or of Spanish words derived from Arabic, and which could not be reduced to the simple notion that the Muslim conquest represented a radical rupture in the history of Spain, reflected in the language. The need to establish a border cordoning off the immediate Muslim past, which remained present in a local landscape peopled by Moriscos and dotted with Arabic buildings, coincided with an urge to affirm the Christian nature of the city, its link to a sacred past and the ancient presence of Christians in the region. This urge explains, for instance, the attempt to find extremely ancient Hebrew etymologies for a number of Andalusian place-names, as in the work of the Cordoban painter and humanist Pablo de Céspedes: ${ }^{30}$ according to Céspedes, the name of Córdoba itself derived from Hebrew, as did the following names: el arroyo del Moro, la dehesa de Morata y Moratilla, las Quemadillas, el pago de Cozar, el de Hojamaimon, la villa de Adamuz. Other place-names, whose Arabic or Hebrew origin might be considered doubtful, were all inevitably endowed with a Hebrew origin: the pastureland of Albaida, for instance, with its addition of the Arabic article 'al' ('of which the Arabs were so fond, and which during the time they occupied this province they attached to many names, where they remain to this day'); or the Arrizapha, which according to the history of Alfonso $\mathrm{x}$ derived from Arabic, was actually of Hebrew origin, as had been confirmed to Céspedes himself by the famous doctor and Morisco translator Miguel de Luna, already mentioned as one of the leading characters in the affair of the Lead Books. In the case of some place-names, such as Córdoba, the Arabic language had served to maintain the pronunciation of some older phonemes; Céspedes was convinced of the 'integrity and faithfulness [of Arabic], so uncorrupted is that tongue, for it preserves itself much more than ours and others in Europe'. The reason for searching out a Hebrew origin for Cordoban placenames was obvious: the first people to settle in Spain had been descendants of Noah and spoke Hebrew. Even the mosque of Córdoba turned out in this view not to be the work of Muslims, but a much older temple, dedicated to the god Janus, who could be identified with Noah. ${ }^{31}$ Within this context can also be

Humanismo y Contarreforma en la cultura andaluza del Renacimiento al Barroco, Granada, 1993, pp. 464-8. In the same volume, see also the anonymous text 'Comentarios sobre el origen hebreo de Granada y cómo la lengua española tiene un principio distinto a la latina, de algún humanista granadino contemporáneo de Bernardo de Aldrete', pp. 4736.

$30 \quad$ Ibid., 'Tratado de Pablo de Céspedes sobre el topónimo de Córdoba y otros lugares cercanos y sobre hijos ilustres cordobeses', p. 312 and et seqq.

$31 \quad$ Ibid., 'Discurso sobre la antigüedad de la catedral de Córdoba y cómo antes era templo del dios Jano, de Pablo de Céspedes', pp. 325-53. 
placed similar efforts to de-Islamize and de-Arabize the peninsula's past in order to re-affirm its biblical antiquity through reference to mythical 'Tubalism' which, following the lead of the influential forgeries of Annio de Viterbo, made Tubal the first settler of Spain; thus, the name of the city of Tarifa was to be derived from Tarsis, the nephew of Tubal, 'however much some moderns with their lack of scholarship wish to derive it from Tarif the Arab invader of Spain'. ${ }^{22}$

The same defence of the notion of a Hebrew origin was carried out by other Granadan scholars with reference to their own patria or homeland. In this case, however, the problem of the Arabic language became more pressing, as is shown by the affair of the Lead Books, which had turned Arabic into a tool for the early evangelization of Granada and its sacred history. A considerable bibliography grew around the subject of the Granadan forgeries, and it often insisted on the idea of the ancient Jewish foundation of Granada, and the Hebrew origin of part of its toponymy as well as its anthroponymy. ${ }^{33}$ One very explicit statement of these ideas is the one made by Pedro Velarde de Ribera, canon of the church of San Salvador in Granada, in his Historia eclesiástica del Monte Santo. ${ }^{34}$ According to Ribera, Granada had been inhabited since ancient times by the Ten Lost Tribes of Israel, who had also settled in America, as was proved by the existence among American Indians of Hebrew words and the practice of circumcision. These Jewish settlers spoke Hebrew; in fact, if Saint Paul went to Arabia (as is stated in a well-known passage of the Letter to the Galatians), it is because he was 'inspired by the Holy Spirit to communicate the language of the Arabs which was so greatly needed for the conversion of the ten tribes that were dispersed among diverse provinces of the world and in order to be able to speak to our holy saints San Cecilio and San Tesifón, disciples of Christ and the Apostle Santiago.'35 This explanation made a clear distinction between the Arabic Jews, ancient settlers of Granada, and the 'moros' or Moors, i.e., the Muslims who had arrived in the eighth century and who tried to erase all traces of their predecessors and 'to usurp for themselves and attribute to their forebears the foundation of one of the noblest cities in

32 J.P. de Ossau and J. Tovar, Población y lengua primitiva de España, recopilada del aparato a su monarchía antigua en los tres tiempos, el adelón, el míthico y el histórico, Valencia, 1672, fol. $21^{\mathrm{v}}$.

M. García-Arenal and F. Rodríguez Mediano, 'Jerónimo Román de la Higuera and the Lead Books of the Sacromonte', in The Conversos and Moriscos in Late Medieval Spain and Beyond, ed. K. Ingram, Leiden, 2009, pp. 243-68.

Pedro Velarde de Ribera, Historia eclesiástica del Monte Santo, ciudad y reyno de Granada, BNE, MS 1583 
Spain'. ${ }^{36}$ This distinction between the old 'Arabic Jews' and the 'Moros' was of course reflected in genealogy: surnames from the kingdom of Granada, like that of Zacharías of the Alcazaba, or the Gabanis, of the tribe of Gad, the Judentis or Cudentis, all descended from these old Jewish settlers of Spain and had continued to exist during the time of the Muslims. The proof of the antiquity of these lineages was 'the skill they had in speaking our Castilian tongue, keeping in it the property and pronunciation of terms which it is clear to see that they had preserved as the tongue of their forebears together with the Arabic they spoke as their vulgar tongue, which is no small argument for proving the antiquity of our language. ${ }^{37}$

Another apology for the Arabic language can be found in the works of the Morisco Jesuit Ignacio de las Casas, an extremely interesting figure whose reflections on the use of Arabic were closely linked to the problem of evangelizing the Moriscos, with De las Casas going so far as to argue for the establishment of special schools for Granadan Morisco children. ${ }^{38}$ In his defence of the Arabic language, De Las Casas stated that the Three Magi were Arabs, and that Prester John in Ethiopia, a potential Christian ally against Islam, was descended from one of those Magi and was himself therefore Arab. In his eagerness to deIslamize the Arabic language, De Las Casas argued that the enduring use of Arabic over so many centuries was not due to the rule of the Muslims, since the example of the Ottomans showed that, although they held power, they had not managed to enforce the universal usage of Turkish ('on account of its being barbarous and limited and as different from Arabic as broad Basque is from Castilian'); instead, Arabic had spread and survived on account of its elegance and expressiveness, which was comparable to that of Greek and Latin. Arabic grammar followed a series of rules thanks to which it was possible to deduce the entire language from just three radicals, 'and this is where its ease comes from which is consistent with that of Hebrew and there is no other language that has this except these two'. This comparison with Hebrew was traced back as far as the Bible: 'If the Hebrew language is so highly esteemed it is because it is thought that it was spoken not only by our first fathers the patriarchs and prophets but by Jesus Christ our lord, the apostles and disciples, and Arabic is owed no small honour, tracing part of its ancestry back to Ruth the Moabite

\footnotetext{
$36 \quad$ Ibid., fol. $24^{\mathrm{v}}$.

37 Ibid., fol. $26^{\text {r. }}$.

38 F. de Borja Medina, 'La Compañía de Jesús y la minoría morisca (1545-1614)' Archivum Historicum Societatis Jesu, 57, 1988, pp. 4-137. See also Y. Alaoui, Jésuites, Morisques et Indiens. Etude comparative des méthodes d'evangelisation de la Compagnie de Jésus d' aprés les traités de José de Acosta (1588) et d' Ignacio de las Casas (1605, 1607), Paris, 2006.
} 
who was a native of Petra [...] and for having chosen the nobility of the Three Magi, initiators of the Church and these were Arabs according to most and the best sources'. Arabic, then, was not only the language of Muslims, but that of Jews and Christians. ${ }^{39}$

In this way, the attempt to integrate Arabic culture into the Hispanic world was based on a process of de-Islamization of the Arabic language, disconnecting it from the Andalusi past of the Iberian Peninsula and linking it, at the same time, to an ancient history that was Oriental, biblical and sacred and which gave proof of Spain's role in the economy of salvation. The events of the Sacromonte show that this argument was used by important exponents of the Spanish Catholic clergy of the Counter-Reformation, who were anxious to construct the legitimacy of Spanish sacred history; it was also used by members of the important groups of Hispanic conversos, of Jewish and Muslim origin, who were able to claim that Jews or Arabs (or Arab Jews) formed part of that same sacred history as agents of the earliest evangelization process in Spain. Their descendants, it followed, could therefore become part of the early modern Hispanic cultural model.

However, all these problematic and multi-faceted attempts to promote an Orientalizing, Arabic, Hebrew and biblical cultural model revolved around another issue, which related to the tension which existed between local forms of knowledge and the construction of an erudite style of knowledge. As was seen in the quotation from Cabrera de Córdoba, tradition constituted the continuity of a knowledge transmitted from parents to children which was based on several foundations, including toponymy and chronology. From this point of view, the Arabic language harked back to a tradition that had crystallized in local knowledge that could be restored through oral inquiries. Thus, Velarde de Ribera wrote how useful it had been for him to make use of 'the long dealings and communication I had with many learned and ancient Moriscos of this kingdom, having been a priest and beneficiary in my first beginnings in many places where they lived, and I was always curious to inquire about their antiquities, for it is well known that these people are always very keen to uphold their traditions, and in this way I was able to know of the many ancient lineages among them who among the Moors themselves were thought to be descendants of the first settlers of this land [...]. ${ }^{40}$ It is quite common to find cases of historians, scholars or priests who interviewed elderly Moriscos in attempts to penetrate the murky depths of local history, and tried to reconstruct the toponymic, genealogical and cultural continuities, as in the following quote about 
that 'very old Moorish woman in the bishopric of Jaén, who remembered the first war of Granada; and on the very site of the Sacro Monte the Moorish women used to wash clothes for devotion in a nearby spring or stream saying that good health stuck to their clothes, without knowing why [...].41 The fact that an Arabic and Muslim tradition existed in Spain constituted, as we have said, a very notable singularity with respect to other European regions and this shaped the way of approaching the issue of Oriental languages, and Arabic in particular. In addition, the tension between local tradition and erudite knowledge was also, in the case of Arabic, a tension between dialectal Arabic and what might be called classical Arabic. This was to be one of the key points in the controversy surrounding the Lead Books of the Sacromonte: its detractors were to say that the Arabic of the Lead Books was dialectal, like the Arabic spoken by the Moriscos, and that this proved that the texts were a forgery, whereas their defenders held that the language used was a very ancient form of Arabic which no Morisco could possibly know. Within the framework of the issue of the writing of the sacred history of Spain, the conflict between dialectal and classical Arabic was also a religious and linguistic conflict between local Morisco culture and the culture of eastern Arabic Christianity. Tradition, history, erudition; an eastern model versus a classical one; dialectal Arabic versus written Arabic - these tensions were reflected in an exemplary manner in the work of Diego de Guadix.

\section{Diego de Guadix}

Diego de Guadix was a Granadan priest from Guadix who lived at the time of the discovery of the Sacromonte Lead Books and who worked as an interpreter for the Inquisition tribunal of Granada in 1587. As he himself explains in his work, he had learnt Arabic as a child, as a result of living in an area populated by Moriscos. In the 159 os he travelled to Rome, where he collaborated with the Tipografia Medicea Orientale, forming part of the committee entrusted with the task of preparing an Arabic translation of the Bible under the management of Giambattista Raimondi, the great Roman Arabist of the period. It was in Rome that Guadix wrote his Recopilación de algunos nombres arábigos que los árabes pusieron a algunas ciudades y a otras muchas cosas (Compilation of some Arabic names that the Arabs gave to some cities and many other

$41 \quad$ Fernán Pérez de Torres, Discurso sobre el Monasterio de San Christóval de la ciudad de Córdova en tiempo de los Moros; cuios vestigios se descubrieron con la creciente de Guadalquivir del año 1626 ... Al Ylustríssimo Señor $D^{n}$. Christóval de Lobera Obispo de Córdova, del Consejo de Su Magd., BNE, MS 1742, fols $49^{\mathrm{v}}-50^{\mathrm{r}}$. 
things). ${ }^{42}$ Although it remained unpublished during his lifetime, this work had a considerable influence on other linguists. Guadix was, for example, an informant of Sebastián de Covarrubias, the author of the most important Spanish dictionaries of the sixteenth century and one of the cornerstones of Spanish lexicography.

The Recopilación de algunos nombres is an etymological dictionary of place names and Spanish (and non-Spanish) words which, according to Guadix, derived from Arabic. The result is an overwhelming catalogue which in practice amounted to a claim that Arabic was the origin of Castilian Spanish. Of course, the majority of these etymologies are mistaken and are deduced from fortuitous phonetic resemblances. There is nothing in Guadix's work that remotely resembles what might be considered serious etymological research, even by the scholarly standards of his time. However, the massive attribution of an Arabic origin to so many Spanish words is interesting because of the cultural programme which it reflects, and which Guadix himself explains in the fascinating introduction to his work. Guadix wrote that although many Arabic words were introduced into Spain by the Muslims, the Arabic language should not be identified with Islam; on the contrary, it was a very ancient language, practically the same as Hebrew, the original language of mankind. In Guadix's words, 'the Arabic language is the oldest of all the languages in the world, because it is the same as Hebrew - although corrupted - and Hebrew was the tongue that Adam, Noah, Abraham, etc., spoke. Therefore, if we were to find some word or verb that was common both to Arabs and to Spaniards or Italians or other peoples, we could not say that Arabic took it from Spanish or Italian or any other tongue, but rather that Spanish or Italian or any other borrowed and took it from Arabic, that being the oldest language [...]. I, who have some knowledge of this Arabic language, have looked into it with some curiosity and seen that if we examine some verbs and nouns used by the Latin tongue and remove the mask of being conjugated and declined as in Latin, and acknowledging the theft, I can say that I know how they were stolen and taken from Arabic.43 In this manner, the Arabic language and its antiquity had to be measured not against the time of the Muslims, 'the sect of the Moors', but against that of the nation of Arabs; for example, the Hebrews who inhabited the

42 D. de Guadix, Recopilación de algunos nombres arábigos que los árabes pusieron a algunas ciudades y a otras muchas cosas, eds E. Bajo Pérez and F. Maíllo Salgado, Gijón, 2005; and Diccionario de arabismos. Recopilación de algunos nombres arábigos, ed. M.Á. Moreno, Jaén, 2007.

43 D. de Guadix, Recopilación, pp. 149-150. 
Arabian peninsula, who spoke Arabic and were for that reason known as Arabs, 'many centuries before Abraham'. ${ }^{4}$

Guadix takes this idea further in his entry on the word 'algarabía', Arabic. ${ }^{45}$ In the period after the destruction of the Tower of Babel and the confusion of tongues, there was 'a nation and community of Gentiles whose language was Hebrew and Hebraic, and these Gentiles, living under a natural law and speaking their Hebrew language for many centuries and thousands of years' until the arrival of Abraham, who founded the community chosen by God, who imposed upon him the 'sacrament of circumcision'. These people were called Jews because they lived in Judea. Further thousands and thousands of Hebrews, 'remaining in their gentileness, lived under natural law and spoke their Hebrew language and, taking the name of the province and land where they lived, which was Arabia, were called Arabs.'Thus the Hebrews were divided into two groups, Jews and Arabs, who both spoke Hebrew. The former 'had law, promises and prophesies and thus they had books and scriptures, and, as a political community, they preserved and upheld the integrity of their Hebrew language'; the latter, 'as a people without law, books or scriptures, became barbarous $[\ldots]$, and corrupted their natural and Hebrew language so much that it lost the name of Hebrew and took its name from the provinces where they lived.' The enmity of these Arabs towards the Jews was great and lasted many centuries, during which they turned their backs on the Jewish religion and the integrity of the language, to such an extent that they even changed the characters and invented a new alphabet. From that moment on, the Arabs began to have books and scriptures, and started to bring 'reason and grammatical art' to their language as well as 'cadences of nominatives for which they invented six cases'. However, 'they did not invent or create pronouns because they did not want to lose the affixes of their Hebrew language; [...] and everything that in Latin grammar serves the nominative quisvel qui, was included by them in the relative particles aladi, aladina, alati, alatina; they assigned certain prepositions $[. .$.$] to the cadences of the nominatives; and from certain particles in their$ language they made adverbs; and from others, verb participles with another thousand little rules of Arabic spelling and grammar.' These Arabs, 'with this Arabic language of theirs and their smattering of Hebrew grammar', filled the world from the Levant to Guinea, and throughout Europe and the Indies. To such an extent did the Arabic language become universal, that a scholar like Clénard had said sola lingua arabica facit interpretem, 'he who knows no more than the Arabic tongue is an interpreter of the world'.

\footnotetext{
44 Ibid., p. 151.

45 Ibid., pp. 257-64.
} 
From these basic notions Guadix derived the idea that, contrary to what was believed by many, there were Arabic names even in territories which had not been conquered by the Muslims (in Guadix's circular view, this was excellent evidence of the antiquity of Arabic). One clear example of this, according to Guadix, was America, where not only Arabic words such as çamí, cacique, zara or caçabe, were used, but even the place names México and Perú were of Arabic origin; ${ }^{46}$ the same could be said of the words Biscay, Flanders, Italy or France. Indeed, Guadix's catalogue includes explanations of a good many Italian and French place names, such as Asis, Mantua, Angoulême or Ardennes. ${ }^{47}$

In an attempt to explain the linguistic evolution of words since their Arabic origin, at the beginning of his work Guadix gives a series of warnings to be taken into account: some words exist which are compounds of Arabic and Romance elements; some phonemes exist in Arabic but not in Romance and vice versa, e.g. the "p" sound (which despite this assertion was in fact used by Turks and Persians); in Arabic, the assimilation of solar letters to the article, with one important Iberian exception: in the kingdoms of Valencia and Granada, the letter jim functioned as a solar and was assimilated into the article. In this respect, added Guadix, "because to some attentive reader who might know Arabic, it will seem curious to assign or say that there is another letter xemçi or solar apart from those explained above, which are those assigned as xemci in all Eastern grammars, say to me or pronounce for me the names alchar, alchoray, alcheuza, and you will see that in good Arabic pronunciation you must pronounce them achar, achoray, acheuza." ${ }^{48}$

As has already been pointed out, the result of these premises expressed by Guadix is that the problem of etymologies and place names was placed in a broad perspective which harked back to the antiquity and sacredness of Arabic and Hebrew. It is thus hardly surprising that Arabic etymology should be called upon to explain terms as characteristic as 'güelfo', 'gibelino' or even 'Papa' (Pope) which, in Guadix's view, derived from the Arabic baba, 'father'. According to Guadix, 'the name of father is well suited to him who is superior to all the prelates of the world, who are the spiritual fathers of their subjects; he is thus a father of fathers [...] and even here, in the Latin and vulgar language, they have always called him padre sancto and padre beatíssimo; I do not

\footnotetext{
46 Ibid., p. 153 .

47 It should be noted that Guadix is not always consistent: when he explains, for example, the etymology of Ardena/Ardennes, he writes that no one should be surprised by the existence of Arabic place names in France, given that the Muslims arrived there in the eighth century, Ibid., pp. 332-3. 
know why this Turkish or Arabic word or term, $b a b a$, has been so well known that almost all the world uses it in this corrupted form, papa, who introduced this Turkish or Arabic name, when or where it started to be used can be said by whoever knows more history than I.49

\section{Christian Arabic: The Rise of Arabic Scholarship}

There are at least two aspects to remark upon in Guadix's profoundly ahistorical analysis. The first has to do with the issue of religion and its connection with the use of the Arabic language. As has been mentioned already, Guadix wrote his compilation in Rome, where he worked with Giambattista Raimondi and the Tipografia Medicea Orientale on editorial tasks relating to the Arabic translation of the New Testament. When the Tipografia was founded, Cardinal Ferdinando de Medici himself ordered 'that the Holy Bible, in particular, be printed in Arabic in its entirety or part by part at first; and also all the Catholic books of Scripture that could be found in the said language; this is for the benefit of the Arab Christians who are in the East, and the Granadans in Spain. ${ }^{50}$ This quotation seems to suggest that from Rome's point of view there was a certain degree of identification between eastern Arabic Christianity and the Arabic Christians of Granada. This identification was often to be offered as proof during the controversy over the Lead Books, when attempts were made to defend the existence of an ancient Hispanic Arabic Christianity, endowed with a textual tradition equivalent to that of eastern Christians. To cite just one example, taken from an author already mentioned above, Pedro Velarde de Ribera replied to the criticisms made of the authenticity of the Lead Books and the appearance in them of the term 'Trinity'. For critics, this was a clear anachronism, since the Trinity did not make an explicit appearance in the Scriptures, but was a notion that had been established later, by the Fathers of the Church. Ribera responded to such criticism by writing that 'where it says in the name of the highly honoured Trinity it is written in Arabic, and not in Latin, and the Arabic term which in Spanish goes by this name of Trinity is not modern but ancient, as is declared by the Arabs who know of it, and it is clear that the Arab Christians of the early Church believed in the mystery of the Holy Trinity as they had learnt it from Christ and his Apostles, who had in their language a term with which to explain this mystery. ${ }^{51}$ Guadix himself was not indifferent to some important theological issues relating to Arabic, Islam and the Lead Books, such as the crucial matter of the Immaculate Conception:

49 Ibid., p. 869.

$50 \quad$ A. Tinto, La Tipografia Medicea Orientale, Lucca, 1987, p. 95.

$5^{1} \quad$ P. Velarde de Ribera, Historia eclesiástica, fol. $250^{\mathrm{v}}$. 
in one passage he speaks of how the Moriscos considered Jesus 'a very great prophet' and accepted the virginity of Mary, 'saying that the Blessed Virgin, Our Lady, conceived Christ our Redeemer when the Holy Spirit breathed in her face, so that she was a virgin before giving birth; and they say it on account of these words in Arabic: maulina mariem bacaadra acalb al-nafiç gua falnafiç guabaa dalnafiç. 52 But this problem of the Christian Arabic language was, at this point in the sixteenth and seventeenth centuries, an important one for the Church of Rome. This was a key moment in the establishment of a theological and linguistic canon of Christian Arabic, with a leading role being played by the Maronites who had arrived in Rome and other parts of Europe. One of the results of this interest in Arabic Christianity was a boom in editions of Christian Arabic texts, starting with those of the Tipografia of Raimondi. When the Lead Books arrived in Rome and were studied by Vatican experts, the problem immediately arose of the theological and linguistic gap between those ambiguous products of Morisco culture and the Arabists of Rome, who were trained in the eastern tradition. ${ }^{53}$

A second aspect which can be highlighted in Guadix's work is its peculiar status in the way it considers the Arabic language, influenced as it is both by direct experience of the Morisco community and the problems related to mass conversion and evangelization, and by the rise of a scholarly interest motivated by a concern to write the history of Spain. Guadix sometimes makes allusion to his own life, including both his childhood growing up among Moriscos from whom he learnt Arabic and his experience as a preacher in the kingdom of Granada: 'And I, who, in public and in secret have preached many times in this Arabic language to Moriscos and Arabs, and all the natives of the kingdom of Granada who have grown up among Moriscos know well how we can report and certify the customs and humour of the Arabs or Moors and Moriscos who lived and live in Spain. ${ }^{54}$ But his involvement in the Arabic Bible project placed him in a very different environment. It is hardly necessary to emphasise the importance of Raimondi and his Tipografia for the history of early modern Italian and European Orientalism: learning Arabic, Hebrew and other eastern languages, collecting manuscripts, fixing and printing texts, creating a scholarly body of knowledge, were all activities which defined the construction of a particular kind of knowledge of eastern languages. Diego de Guadix was not an outstanding scholar but his concern, though simple, for

\footnotetext{
$5^{2} \quad$ D. de Guadix, Recopilación, p. 170.

53 We analyzed this in more detail in García-Arenal and Rodríguez Mediano, The Orient in Spain.

54 D. de Guadix, Recopilación, p. 187.
} 
grammar, the reduction of a language to a set of rules, the establishment of criteria for an understanding of the evolution of words of (allegedly) Arabic origin, were all signs that he was moving in a different direction from that which one would expect to be taken by a simple priest from a village in the kingdom of Granada. Although quotations from other works are not common in his work, some can be cited, such as those from Abraham Ortelius, or, as we have seen, Nicholas Clénard or Clenaerts. The latter quotation has a certain significance: we have already seen that one of the main translators from Arabic of the Spanish seventeenth century, the Morisco physician Alonso del Castillo, one of the first translators of the Lead Books, knew Arabic because of his Morisco background but had to learn 'classical' Arabic with the Flemish master, according to contemporary sources. Other learned Moriscos went to study Classical Arabic with Joseph de Herrera, interpreter of Arabic of the Inquisition of Granada. ${ }^{55}$

The story of Clenaerts and Castillo or of the Granadan Moriscos and Herrera, are just examples of an awareness of the gap between the world of dialectal and classical Arabic, definitively illustrated by the significant existence of a version of the Äjurrümiyya in aljamía, i.e., Spanish in Arabic script, which shows that it was also an instrument used by Moriscos for the study of Arabic. ${ }^{56}$ This leads us to the following question: how could an interested person learn Arabic, whether he was a historian wanting to make use of Arabic sources or a philologist wanting to study Oriental languages because of their closeness to Hebrew, or a learned Morisco wanting to know the Classical tongue and not just the dialect?

Tentative attempts to institutionalize Arabic teaching during the sixteenth century culminated in one significant milestone, the creation of a Chair of Arabic at Alcalá de Henares, first held by Diego de Urrea. Urrea was a fascinating character: a Calabrian captured by North African corsairs who converted to Islam, became a high-level functionary serving various Ottoman lords, then converted back to Christianity under the name Diego de Urrea, became an official translator of Arabic, Turkish and Persian for the king of Spain and, finally, was a member of the Neapolitan branch of the Accademia dei Lincei who sought to collaborate with Cesi and Galileo. ${ }^{57}$ During his brief spell as

\footnotetext{
55 Velarde de Ribera, Historia eclesiástica, fol.182 ${ }^{\mathrm{r}}$. See the contribution of Nuria Martínez de Castilla Muñoz to this volume.

$5^{6}$ On the Ājurrümiyya see L. López-Baralt, “A zaga de tu huella”. La enseñanza de las lenguas semíticas en Salamanca en tiempos de San Juan de la Cruz, Madrid, Trotta, 2006. pretes y traductores de los "Plomos"', in Los Plomos del Sacromonte, invención y tesoro, eds M. García-Arenal and M. Barrios, València et al., 2006, pp. 297-333.
} 
professor at Alcalá de Henares, Urrea, occupied with other tasks, was unable to attend to his classes as much as he ought, judging by the complaints of students who protested that he never taught them more than the fundamentals. This complaint shows that whoever wished to study Arabic in Spain at that time came up against the gulf between the modern dialect spoken by Moriscos and North Africans and 'ancient Arabic'; furthermore, that basic texts for learning the latter were lacking. Benito Arias Montano, for instance, wrote to Archbishop Pedro de Castro: 'I have put all possible effort into ancient Arabic until I was able to understand the holy books written in it, for which I had some information about grammar, as will be seen one day; but I have not worked on other topics written in the language for lack of time and lack of books, especially good vocabularies. We have none of those here nor have I been able to create any through my inquiries, and the licentiates Luna and Castillo have not told me that they possess them, although I have asked them about it. ${ }^{58}$

Arias Montano's reference to 'ancient Arabic' shows that as a scholar he was fully aware of the difference between classical and dialectal Arabic, and of the separate spheres of knowledge and activity which they involved.

Other examples could be added to illustrate the two dimensions of the same problem: to learn Arabic in sixteenth-century Spain was to attempt to bridge the gap between dialectal Arabic and written Arabic; it also meant facing up to the lack of suitable grammatical tools to learn it. Again, it is possible to detect an increased interest in Arabic grammar and the collection of textual materials for learning the language at around the time of the Sacromonte findings. It is also possible to detect the production of materials. For instance, a set of manuscripts produced around the Sacromonte provides us with clues about the incipient ways of learning Arabic, in the miscellaneous and disorganized nature of what appear to be notebooks: thus, manuscript 8434 of the Biblioteca Nacional contains, among other things, texts from the epistles of St. Paul in Arabic, with interlinear translations in Latin and Spanish; fragments of the

$5^{8}$ 'En la lengua arábiga antigua he puesto la obra que me ha sido posible hasta entender los libros sagrados que están interpretados en ella, y para esto he tenido noticias de la Gramática, como algún día se verá, pero en las demás disciplinas que en ella están escritas no he trabajado por falta de tiempo y de libros, y sobre todo por falta de buenos vocabularios, que no los hay entre nosotros, ni yo los he podido hacer con diligencia, ni el licenciado Luna ni Castillo me han dado intención de que ellos los tengan por allá, aunque por mi parte se les ha preguntado': Diario del viaje desde Valencia a Andalucía hecho por don Francisco Pérez Bayer en este año de 1782, BNE, MS 5953, fol. $174^{\mathrm{r}}$. 
Ājurrūmiyya (i.e. the Muqaddima of Ibn Ājurrūm); exercises in Arabic grammar and conjugation; tentative translations of the Lead Books and a Spanish translation of the Käfya ${ }^{59}$ Manuscript 8432 contains exercises in Arabic conjugation and declination, manuscript copies of the Ājurrūmiyya and the Käfyya, a Spanish translation of the Äjurrümiyya, and exercises with Arabic characters used in the Lead Books. ${ }^{60}$ To these examples can be added other especially interesting ones, such as the complex Arabic grammar held at the University of Granada, made up of 253 folios and composed in the early seventeenth century which we have attributed to Marcos Dobelio, ${ }^{61}$ a Kurdish eastern Christian who had been a professor of Arabic at La Sapienza and also to Prince Federico Cesi in Rome before arriving in Spain to translate the Lead Books, and whose profound Arabic culture had allowed him to carry out the first scholarly criticism of the Books, in which he identified their Muslim origins.

\section{Conclusion: Orientalist Erudition}

This store of grammatical materials constitutes a key step in understanding how Arabic became the object of a particular form of knowledge, a tool for the comprehension of the Spanish past, and not just an alien element to be removed, as the Moriscos themselves had been. To illustrate the distance covered, let us give an example relating to toponymy, taken from the writings of a seventeenth-century Spanish Orientalist scholar: 'As for the etymology of the term Moncada, concerning which Your Excellency asks me whether it is Arabic; as Your Excellency assures me with Escolano; it can have very different meanings, depending on the three ways in which it is written, which form different roots: for as Your Excellency knows best, the Arabs have two forms of C. which are the قaf, and the كef: and four forms of D. which are the Dal, the Dhal, Dad, and Da: according to the dictionary of Erpenius, of the Maronites, and other Arab grammars [...]. And because Your Excellency likes to see proof in texts. In the Psalter of the Maronites Arabic psalm. 17. v. 22. Reads أُقََْنَ Ancadhani: liberauit me; quoniam ipse propitiatus est mihi: Ancadhani"leannahu taraaf bi. Ancadhani leannahu taraaf bi: liberauit me; quoniam ipse propitiatus est mihi $[s i c]$ : vers. 9o: Exaltetur [??] Deus, qui redemit me. in Arabic : Ancadhani. أنقَُدَني Psalm. 24. v.12. Redime me, o [... ?] : Arabice: Ankedhni. I refrain from

59 Del señor Conde de Miranda, BNE, Ms 8434.

6o Ayurrumía en árabe trasladada en Romance, del señor Conde de Miranda, BNE, Ms 8432.

$61 \quad$ García-Arenal and Rodríguez Mediano, The Orient in Spain, p. 264. 
quoting further for I have no more space on this sheet; and Your Excellency will find them in the Pentaglotto, and Polyglotto de Castelo: [...].'62

This late seventeenth-century example shows how far removed its author was from the world of local knowledge, from the tradition of an Arabic culture that was sought out by questioning elderly Moriscos; scholars like the one we have cited now looked for the origins of Andalusian place names in the dictionary of Golius, in Erpenius, or in al-Idrīsīs Geography. Between one period and the next, a crucial process had taken place: the growing awareness that books written in Arabic were a key source of information for the writing of the history of Spain. This process was a long and painful one: identification of Arabic with Islam was long and deep, and there is no doubt that this was one of the reasons why books were not printed in Arabic in Spain until a very late date by contrast with what occurred in other European countries where Islam did not form part of the historical narrative. However, from the sixteenth century on, a number of significant authors pointed out the need to take into account Arabic sources for the writing of Spanish history, and it is not uncommon to find criticisms like that made by a seventeenth-century scholar, the Marqués de Mondéjar, concerning the work of Father Juan de Mariana, perhaps the most important Spanish historian of the early modern period, in which he reproached Mariana for having written about the Arabs without taking Arabic books into account, for which reason it was impossible for Mariana not to 'make continuous absurd mistakes'.63 It was not until the eighteenth century, however, that a Lebanese Maronite monk, Miguel Casiri, sponsored by an enlightened Crown minister, the Count of Campomanes, tried to highlight the definitive value of the extraordinary collection of Arabic books at the library of El Escorial. ${ }^{64}$ The presence of a Maronite whose role turned out to be crucial in the development of Arabist knowledge clearly does not require us to accept the idea of Spanish singularity. It does, however, reveal other interesting features, such as the difficulty experienced by Spanish scholars in connecting with their own Andalusi past via the extraordinary collection at El Escorial and in systematically recording the items held there. This shortcoming was partly redeemed by having recourse to European Orientalist bibliography.

62 Letter from Fray Joseph Joy to Marqués de Mondéjar, Alcalá, 25July 1693, Varias cartas de erudición, BNE, MS 9881, fols 190-1.

63 M. de Mondéjar, Advertencias a la historia del padre Juan de Mariana, Valencia, 1746, p. 43.

64 M. Casiri, Bibliotheca Arabico-Hispana Escurialensis, 2 vol., facs. ed. of the edn of 1760-70, Osnabrück, 1969 . 